\title{
Foresight for Career Development
}

\author{
Anna Kononiuk ${ }^{\mathrm{a}}$ \\ Assistant Professor, a.kononiuk@pb.edu.pl
}

Anna Pająk ${ }^{b}$

Assistant Researcher, anna.pajak@itee.radom.pl

Alicja Ewa Gudanowska ${ }^{a}$

Assistant Professor, a.gudanowska@pb.edu.pl

Andrzej Magruk ${ }^{\mathrm{a}}$

Assistant Professor, a.magruk@pb.edu.pl

Ewa Rollnik-Sadowska ${ }^{a}$

Assistant Professor, e.rollnik@pb.edu.pl

Justyna Kozłowska ${ }^{a}$

Assistant Professor j.kozlowska@pb.edu.pl

Anna Sacio-Szymańska ${ }^{b}$

Assistant Professor, anna.sacio@itee.radom.pl

${ }^{a}$ Bialystok University of Technology, 45A, Wiejska Street, 15-351 Bialystok, Poland

${ }^{\mathrm{b}}$ Łukasiewicz Research Network - Institute for Sustainable Technologies), K. Pułaskiego 6/10, 26-600 Radom, Poland

\begin{abstract}
$\mathrm{C}$ areer development has become a process of managing learning, experience, and change in order to achieve a personally determined, preferred professional future. In the context of dynamic social, economic, and technological changes, the role of career counseling services increases, although their character also evolves. New competences and abilities to use innovative tools that enable effective processes of creating career visions in a systemic manner are expected. In this context, the adaptation of Futures Studies to both practice and education of career counseling seems to be an interesting prospect. Exploring the future not only develops individual planning and adaptation skills, but also allows for detecting and identifying upcoming trends. It means the ability to adapt to new conditions, or the proactive creation of the future, in a way that is favorable. The aim of this article is to present a comprehensive methodology and the

results of a nationwide survey conducted in Poland among practitioners in the field of career counseling. The scope of the study included an exploration of the potential of the application of a foresight methodology and future studies for education and practice in the field of career counseling. The main focus of this research to examine the current quality and scope of educational offers for career counselors by the disconfirmation between the ideal features of the courses and the individual perception of the completed courses, in the context of building the abilities to apply future-oriented methodologies and tools. Competences in this area were also examined by assessing both their level among the practitioners and the assessment of their suitability in career counseling practice. The quantitative research was supported by individual interviews with practitioners and experts in the area of career counseling.
\end{abstract}

\section{Keywords:}

career development; futures studies; foresight; career counseling services; competences; skills; trends
Citation: Kononiuk A., Pająk A., Gudanowska A.E., Magruk A., Rollnik-Sadowska E., Kozłowska J., SacioSzymańska A. (2020) Foresight for Career Development. Foresight and STI Governance, vol. 14, no 2, pp. 88-104. DOI: $10.17323 / 2500-2597.2020 .2 .88 .104$ 
C onscious planning and creating a vision of one's career with the ability to adapt to the prevailing environmental conditions and dynamic changes today is not only an essential factor for successful professional career development, but also a prerequisite for functioning on a dynamically changing labor market. There is no doubt that the role and nature of the work will continue to change, the question that remains is 'how?'. Many professions may disappear as a result of the adoption of $\mathrm{AI}$ and new emerging technologies but at the same time, new jobs will emerge. According to A. Toffler's statement, the so-called "third wave" in the 21 st century means the need to have the ability to "learn, unlearn, and learn again" [Toffler, 1980]. Key actions in coping with the changing labor market should therefore include such elements as managing one's own competences, including planning an individual educational path in accordance with the paradigm of lifelong learning [e.g. Mocker, Spear, 1982; Knapper, Cropley, 2000; Volles, 2016], the ability to cope with change and adapt to new conditions. There are new challenges in supporting the development of careers of new generations functioning on or just entering the labor market. According to the definition of OECD [OECD, 2004], career counseling refers to services designed to provide support in making educational, training, and vocational choices, as well as career management, including lifelong education and development. Career counseling supports reflection on one's own ambitions, interests, qualifications, and skills as well as understanding the labor market and education system and linking this knowledge with selfknowledge. Counselors are therefore expected to possess new competences and the tendency to create models of career guidance as a holistic, contextual, and preventive solution, such as life-designing, life-constructing [Savickas et al., 2009; Dauwalder, 2014], or career exploration [Stumpf et al., 1983; Flum, Blustein, 2000; Neureiter, Traut-Mattausch, 2017; Jiang et al., 2019] becomes noticeable.

Numerous studies conducted over the last decades on the models and methods of occupational intervention in the 20th century have shown that new approaches are needed, which will transform them into being able to meet the new needs and challenges of the 21st century labor market participants, who operate in a dynamically changing, knowledge-based, and information-intensive societies as part of the globalized economy. Contemporary theoretical models are needed in the area of career counseling that emphasize such characteristics of employees as flexibility, adaptability, and lifelong learning [Savickas et al., 2009]. New career guidance methods should adopt a dynamic approach that encourages individuals to use their imagination, creative thinking, and discover and create new, alternative future professional identities [Guan et al., 2017; Oyserman et al., 2006]. With regard to new concepts in career counseling theory such as career exploration, future-oriented beliefs, such as hopes for future careers or positive beliefs about the future, are important elements of future professional identity next to professional adaptability, which in the last decade was recognized as an important condition for the success of all professional ventures [Jiang et al., 2019].

In this context, the adaptation of methodologies of foresight and futures studies to career counseling practice seems to be advantageous. Basic knowledge and skills referring to the exploration and "use" of the future in various fields -so-called futures literacy - is considered the ability to create and process complex visions of the future and give them new sense. Exploring the future not only develops individual planning and adaptation skills, but also allows one to detect and identify upcoming trends [Nazarko, 2013; Ejdys et al., 2019]. This means the ability to adapt to new conditions, or proactively create the future in a way that is favorable to its recipients [Bednarczyk et al., 2018; Kononiuk et al., 2017b; Magruk, 2017].

The unique proposition of combining career counseling with future studies and foresight is the basis for an interdisciplinary methodology for the research conducted in the framework of the "Horizons of the Future" Project ${ }^{1}$. The project [Kononiuk et al., 2019] focuses on two main thematic areas: a) trends analysis and their potential impact on the labor market and b) the creation of various career development paths. However, to adapt new methods and methodologies to a given field, it is critical to analyze the potential of such a process in a more specific ways. Taking on the challenge of creating "working methodological tools" for successful career counseling by adopting the perspective of foresight and futures studies requires a deeper understanding of the relationship between the two fields, namely: career counseling and foresight and futures studies. Hence, the questions posed in the very first stage of this study are, therefore, i) in the methodological dimension: "what challenges and questions posed by the theory of career development and counseling can be supported and answered by foresight and future studies?"; "what are the common points between career development theories and future studies that may be most relevant to the design of a new interdisciplinary methodology"; ii) in the practical (application) dimension: "what is the attitude of career counselors to the future, especially in the dimension of professional practice"; "how can

${ }^{1}$ Available at: http://horyzontyprzyszlosci.pl/ accessed 03.01.2020 
foresight and futures studies be practically used to support counseling practice"; "what competences are essential in order to successfully adopt futures studies and foresight into career counseling practice and education"?

The authors of this article agree with Rieckmann [Rieckmann, 2012] who defines competence as the "interplay of knowledge, capacities, skills, motives and affective dispositions." According to Symela [Symela, 2006], competences can be defined as the link between individual skills, personality traits, and qualities that are required for the efficient implementation of professional duties. Also, Dubois and Rothwell [Dubois, Rothwell, 2004] connect the term "competencies" with effective work performance. According to European Commission's European Skills Competences and Occupation taxonomy (ESCO), competence is "the proven ability to use knowledge, skills and personal, social and/ or methodological abilities, in work or study situations and in professional and personal development." 2

In order to identify the common points and the areas subject to the questions in the methodological dimension, source texts related to the career development and counseling practice were reviewed. In order to get answers to the questions related to the practical dimension, the study "Competences and the Quality of the Educational Offerings in the Field of Career Ccounseling practice in Poland" was conducted between January and March 2019, followed by a series of in-depth interviews with counseling professionals and representatives of the academic staff training future vocational counselors. The aim of this article is to present the main conclusions of the literature review and the methodology applied for the study of measuring the quality of the educational offerings and competences of career advisors as well as the results of this study.

\section{Research Methodology}

An examination of the quality of educational offerings and an assessment of competences that are relevant from the perspective of career counseling practice was carried out in the first quarter of 2019 among the career advisers and people working in areas related to career support and career development. The methodology of the study consisted of four main stages (Figure 1).

In total, the research involved 253 respondents ${ }^{3}$, practitioners working in the areas related to career counseling and career development and planning, including representatives of employment offices, academic career offices, various levels of schools, as well as academics.

The first stage of the research was aimed at creating the research tools for the implementation of the study. In the first place, it covered the identification of thematic areas of career counseling education and practice in which the futures studies and foresight methodologies could be applied as well as the competences that enable individuals to deal with future-oriented tasks [Kononiuk et al., 2017a]. The analysis focused on two thematic areas of the project: (a) trends analysis and their potential impact on the labor market; (b) creating various career development paths. Desk research was based on the literature review comprising of the revision of: i) scientific articles according to the main keywords: career counseling, vocational counselor, career counselor competences, and their Polish-language counterparts; ii) an overview of European and national qualification frameworks for career counseling and career development practitioners [OECD, 2017; Hiebert, Neault, 2013; DHET, 2016; CEDEFOP, 2009a, 2009b; NCDA, 2009; Sultana, 2004]; iii) a review of legal acts regulating vocational and career counseling in Poland by the Ministry of Education and Ministry of Family, Labour and Social Policy; iv) study programs and syllabuses from six universities in Poland conducting studies in the field of career and vocational counseling and related subjects, as well as the evaluation of a framework program of post-graduate studies in the field of education and vocational counseling [Bielecki et al., 2015].

Taking into account the practical orientation of the project and the purpose of the study, it was decided to indicate key skills as well as tools and methods in career counseling teaching and practice that appear in the source materials selected for the review process (Table 1).

The indicated thematic areas as well as the areas of skills, tools, and methods selected after the literature review, which were considered the most appropriate for introducing the foresight methodology and the perspective of futures studies into career counseling education and practice were then confronted with the areas of knowledge and methodologies in the field of future studies and foresight. Moreover, they have been assigned to the thematic areas of the project, namely: (a) trends analysis and their potential impact upon the labor market; (b) creating various career development paths.

Based on the analysis, potential program content divided into "knowledge" and "skills" categories related to futures studies and foresight methodology were identified (Table 2). "Knowledge" and

\footnotetext{
Available at: https://ec.europa.eu/esco/portal/home?resetLanguage=true\&newLanguage=en, accessed 21.03.2020.

${ }^{3}$ That number includes both respondents of quantitative (240) and qualitative (13) research. The tools of two quantitative studies were delivered to the same group of experts (240 of them participated in the competency gap survey and 178 of respondents filled in SERVQUAL questionnaire).
} 
"skills" categories were used in accordance with the generally recognized division for the design of the educational content and competency frameworks [McClune, Jarnam, 2010; Fernández-Sanz et al., 2017]. Together with the "attitude" or "values" they can be considered the constitutive elements of the potential learning outcomes model. Furthermore, "knowledge" and "skills" next to "responsibility and autonomy" are the main indicators of the learning outcomes relevant to European Qualifications Framework (EFQ) in the context of professional qualifications ${ }^{4}$. In this paper, the "knowledge" category includes topics in which the basis of theoretical knowledge should be provided, which is necessary for using foresight methodologies and futures studies (cognitive domain). The "skills" category includes skills that are necessary to successfully apply foresight methodologies and future studies in practice.

The identified thematic areas were the basis upon which to design the research tools for the quantitative research (evaluation surveys) in the next stages of project implementation. It included:

1. Statements regarding the quality and scope of the current educational offerings in career counseling courses - for the SERVQUAL tool [Ahmed et al., 2017; Ali et al., 2014; Parasuraman et al., 1985].

2. A list of related competences relevant from the perspective of practice and education in the field of career counseling - for the Competency gap tool.

Both tools were elaborated upon by the authors.

In the quantitative study, the following two research hypotheses were tested:

1. Career guidance practitioners in Poland lack skills in the analysis of the external trends impacting the labor market.

2. Career guidance practitioners lack skills in the analysis of the alternative career development paths.

The quantitative research was supported by qualitative research which was carried out using the individual in-depth interview (IDI) technique. Twelve interviews were conducted among 13 experts ${ }^{5}$ - the career advisors and people working in areas related to career support and career development. The main objectives of the qualitative research was to determine the quality of educational offerings and teaching methodologies in the field of vocational counseling and to identify features and functionalities of preferred educational tools used by persons educating vocational counselors.

\section{Research Findings}

\section{SERVQUAL Model Adaptation to Career Ccounseling}

The first stage of the quantitative research was based on the SERVQUAL model [Parasuraman et al., 1985]. It is widely used to measure the quality of a service from the customer's point of view. The authors of the study adapted the model to career guiding practice by developing 24 statements taking into account the specificity of the practice and the extent of applying trends analysis and methods of developing alternative career paths by career counselors. The use of the model allows for the detection of so-called gaps between the quality of the courses offered and the ideal courses in the field of career guidance.

The SERVQUAL survey involved 178 respondents. Each of 16 provinces were represented by at least two respondents. The most numerous respondents were professional advisers from the Mazowieckie (12\%), Śląskie (11\%), and Małopolskie (10\%) voivodships. Almost half of the respondents (82 persons, which constitutes $46 \%$ of the research sample) were in the age group between 35 and 44, one third - between 45 and 54 , and $13 \%$ - over 54 . The majority of respondents were people working actively in the profession of a counselor for over a dozen years. About one fourth of the surveyed advisers (21\%) worked in the profession for more than 15 years, while one third were involved in counseling for less than 15 , but more than 10 years. Slightly over $30 \%$ were vocational counselors with work experience between 5

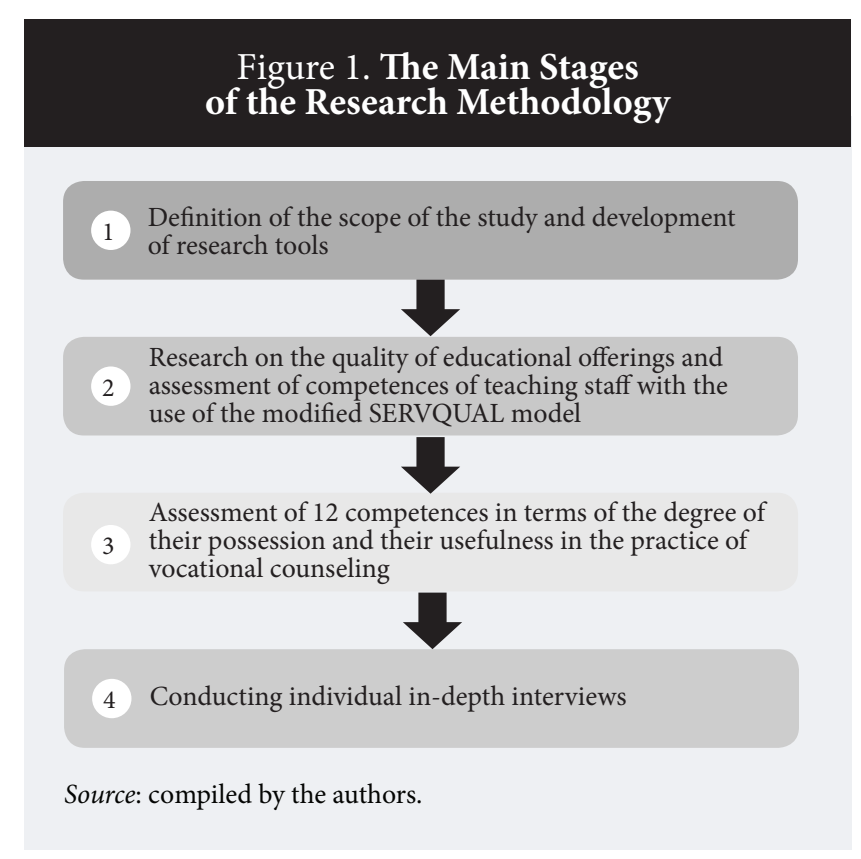

${ }^{4}$ Available at: https://ec.europa.eu/ploteus/en/content/descriptors-page; accessed 17.03. 2020

${ }^{5}$ In one interview, two experts took part. 
Table 1. Skills, Tools, and Methods for Career Counseling Education and Practice in Which the Futures Studies and Foresight Methodologies are Adequate to Apply

\begin{tabular}{|c|c|}
\hline Area & Content examples \\
\hline Skills required & $\begin{array}{l}\text { - Skills in observing, searching for, and processing information on social phenomena of various types, using } \\
\text { various sources, and interpreting them from the point of view of educational problems and professional } \\
\text { development. } \\
\text { - Determining factors influencing the creation of individual career paths. } \\
\text { - Providing support in the selection of educational and vocational paths. } \\
\text { - Abtting goals, tasks, and activities in the context of planning an educational and vocational path. } \\
\text { - } \text { predict to generate original solutions for complex problems and forecast the course of their resolution and } \\
\text { - Ability to set goals, alternative options for action (setting short- and long-term goals, verification of goals, plan } \\
\text { "Br, writing the goal on individual steps necessary to take). } \\
\text { on the balance of one's own resources and values as well as information on the education and labor market, } \\
\text { anticipating the effects of their own decisions }\end{array}$ \\
\hline $\begin{array}{l}\text { Tools and } \\
\text { methods }\end{array}$ & $\begin{array}{l}\text { - Methods of conducting classes, including activating methods taking into account the thematic scope and the } \\
\text { specificity of the group. } \\
\text { - Modern tools and methods in the practice of vocational counseling in youth work. } \\
\text { - Methods and techniques for conducting group classes, including methods that activate, motivate, and engage } \\
\text { participants. } \\
\text { - Methodology of career planning. } \\
\text { Original solutions to complex problems and forecasting the course of their resolution and predicting the effects } \\
\text { of planned activities in specific practical areas. }\end{array}$ \\
\hline
\end{tabular}

and 10 years. The interviewed career advisors were employed at various institutions and organizations. Almost one third of the research sample was made up of advisors from labor offices (31\%). Subsequent groups (in terms of percentage share) included advisors employed at primary schools (16\%), career offices at universities (13\%), technical schools $(11 \%)$, and general secondary schools (8\%). A large group (16\%) were advisers employed in places not indicated in the questionnaire, i.e.: psychologicaleducational counseling centers, voluntary labor troops, education centers, or vocational and lifelong learning centers. For $68 \%$ of the respondents (i.e. 121 persons), work related to vocational counseling was their main occupation. The most popular form of education in the field of counseling in the examined sample were studies - over $80 \%$ of the surveyed counselors gained their education during post-graduate studies, and another $17 \%$ during bachelor studies or master studies. Few advisers (2\%) used full-time or online courses. Over half of the respondents $(62 \%)$ completed education at a public institution, and the remaining part (38\%) chose private institutions.

Table 3 shows the average assessments of 24 statements elaborated upon by the authors concerning the vocational counseling education completed by the respondents, assessed using a seven-point Likert's scale, where 1 means that "I definitely do not agree with the statement" and 7 means that "I definitely agree with the statement".

The last column of the Table 3 also shows the arithmetic means for each statement. The lowest scores were given to statements referring to the use of interactive whiteboards for group work (statement 3 ), online games (statement 4), and interactive educational games in counseling (statement 2). At the same time, these statements obtained the lowest arithmetic means for all responses, which amounted to $2.12,2.09$ and 2.85 , respectively. The results obtained suggest a low level of use of online and interactive educational games in the training of career guidance counselors.

Low scores were also obtained for statements referring to: the development of skills for analyzing scientific and technological trends and their impact on the labor market (3.54) (statement 8), the possibility of choosing one specialization adapted to the specificity of current or future professional practice (3.75) (statement 16), updating didactic content depending on scientific and technological trends (3.96) (statement 17), and economics specialists among didactic staff of vocational counseling (3.94) (statement 19).

On the basis of the conducted analysis, it may also be concluded that the problem of the analysis of scientific and technological trends, such as automation, robotization, digitization, which is the subject of interest of the project, is treated marginally within the framework of education completed by the respondents.

The highest scores were given to statements referring to the atmosphere in which education took place, which was conducive to free discussion (statement 23) and to specialists in psychology among teaching staff (statement 21). At the same time, these statements obtained the highest arithmetic means of 5.71 and 5.39 for all responses, respectively. The ranking of average ratings of respondents is presented in Figure 2. 


\section{Table 2. Potential Program Content and Competence Areas for Applying Foresight} and Futures Studies to Career counseling Education and Practice

\begin{tabular}{|c|c|}
\hline \multicolumn{2}{|c|}{ Thematic area (a): trends analysis and their potential impact on the labor market } \\
\hline Knowledge - what knowledge should a graduate have? & Skills - what skills should a graduate have? \\
\hline $\begin{array}{l}\text { concepts related to the emergence and dynamics of } \\
\text { change in scientific and technological trends, as well as the } \\
\text { implications related to them on the labor market (notions of } \\
\text { trends, megatrends); } \\
\text { the labor market as a system - elements, definitions, features, } \\
\text { actors; } \\
\text { analyses of supply and demand on the labor market and } \\
\text { forces affecting them; } \\
\text { methodologies for analyzing future professions;; } \\
\text { the concept of system and system analysis; features of } \\
\text { complex systems, economic system as a complex system, } \\
\text { social system as a complex system, system connections; } \\
\text { change, change management, theoretical approach; } \\
\text { basic theoretical aspects regarding changes in the context of } \\
\text { the work environment }\end{array}$ & $\begin{array}{l}\text { - stimulate / inspire reflection on the future of people covered by } \\
\text { support and counseling; } \\
\text { Moderate future-oriented thinking processes and group } \\
\text { discussions about the future; } \\
\text { use interactive and engaging tools to implement program } \\
\text { content related to the analysis of scientific and technological } \\
\text { trends as well as economic and social change; } \\
\text { - perform a basic analysis of scientific and technological trends } \\
\text { including the search for and selection of appropriate sources of } \\
\text { and information and content; } \\
\text { - moderate the group process in the field of system analysis and } \\
\text { anticipation of the future; } \\
\text { - perform a basic analysis of changes in the context of the work } \\
\text { environment; } \\
\text { inspire future-oriented reflection on one's own educational and } \\
\text { professional plans; }\end{array}$ \\
\hline \multicolumn{2}{|c|}{ Thematic area $(b)$ creating various career development paths } \\
\hline Knowledge - what knowledge should a graduate have? & Skills - what skills should a graduate have? \\
\hline $\begin{array}{l}\text { wild cards and weak signals; } \\
\text { theoretical basis of the scenario method; } \\
\text { - } \text { thements of storytelling (personalized scenarios); } \\
\text { reflexive writing; } \\
\text { the concept of uncertainty and the differences between } \\
\text { uncertainty and risk, and the importance of uncertainty in } \\
\text { the context of career planning. }\end{array}$ & $\begin{array}{l}\text { - facilitate an individual and group process using scenario } \\
\text { methods in the context of creating individual career paths; } \\
\text { analyze the scenarios and indicate their implications and } \\
\text { meanings as a tool for career planning and promoting the idea } \\
\text { of lifelong learning. }\end{array}$ \\
\hline
\end{tabular}

Table 4 shows the average assessment of 24 statements concerning ideal vocational guidance education assessed on a seven-point scale, where 1 means that "I strongly disagree with the statement", and 7 means that "I strongly agree with the statement".

On the basis of the obtained data, it can be noted that the respondents have high expectations towards education in the field of vocational counseling. This is evidenced by the high average marks obtained, amounting to more than 5.42 and the average of average marks at the level of 6.26 (in the case of completed education, the average of average marks was at the level of 4.31). The highest expectations are expressed in terms of: the atmosphere in the classroom, which should be conducive to open discussion (statement 23), the ability to take a different perspective, understand, and accept different points of view (statement 24), and the content of education, which should include issues related to competences and professions of the future (statement 11).This is evidenced by the high arithmetic means of $6.62,6.58$, and 6.57 respectively. The results also indicate high expectations of respondents as to the need to take into account scientific and technological trends (statement 8), economic trends (statement 9), and social trends (statement $10)$ in educational content. The average score for the three statements is 6.25 . Respondents also have high expectations of being able to create alternative (optional) career paths (statement 6) and to include content on competences and occupations of the future in curricula (statement 11). This is also confirmed by the high arithmetic means for statements of 6.51 and 6.57 , respectively. The ranking of average ratings of respondents is presented in Figure 3. On the basis of the analysis of the data, four gaps are clearly visible. The biggest gap was noted in the comparison of arithmetic mean values perceived and expected by respondents as regards the use of dedicated online game advisors by teaching staff (-3.73) (statement 4).

There was also a large gap in the use of interactive whiteboards for group work by teaching staff $(-3.60)$ (statement 3). An important difference in perception and expectations can also be observed with regard to the use of interactive educational games $(-3.25)$ in the training of vocational guidance counselors. A slightly lower but still significant gap $(-2.57)$ was noted with respect to the development of learners' skills in the analysis of technological trends (e.g., automation, robotization, and digitization) and their impact on the labor market (statement 8). The presented results in relation to the largest gaps show the strong need of respondents to make the form of classes more attractive in terms of group work, gamification, and taking into account scientific and technological trends shaping the labor market. 
Table 3. The Assessment of the Statements Relating to Vocational Guidance Training Completed by the Respondents

\begin{tabular}{|c|c|c|}
\hline & Statement & Arithmetic mean \\
\hline 1 & The teaching staff in vocational counseling training completed by me used modern educational tools & 4.39 \\
\hline 2 & The teaching staff in vocational counseling training completed by me used interactive educational games & 2.85 \\
\hline 3 & $\begin{array}{l}\text { The teaching staff in vocational counseling training completed by me used interactive whiteboards for group } \\
\text { work }\end{array}$ & 2.12 \\
\hline 4 & The teaching staff in vocational counseling training completed by me used online games & 2.09 \\
\hline 5 & $\begin{array}{l}\text { The training in vocational guidance completed by me developed my ability to formulate personal and } \\
\text { professional goals }\end{array}$ & 4.81 \\
\hline 6 & $\begin{array}{l}\text { The training in vocational guidance completed by me developed my skills to create alternative (optional) } \\
\text { career paths }\end{array}$ & 4.57 \\
\hline 7 & $\begin{array}{l}\text { The training in vocational guidance completed by me developed the skills to inspire others to pursue lifelong } \\
\text { learning }\end{array}$ & 5.07 \\
\hline 8 & $\begin{array}{l}\text { The training in vocational guidance completed by me developed skills for analyzing technological trends (e.g. } \\
\text { automation, robotization, digitalization) and their impact on the labor market }\end{array}$ & 3.54 \\
\hline 9 & $\begin{array}{l}\text { The training in vocational guidance completed by me developed skills to analyze economic trends (e.g. factors } \\
\text { shaping labour demand, wage levels, shortage and surplus occupations) and their impact on the labor market }\end{array}$ & 4.16 \\
\hline 10 & $\begin{array}{l}\text { The training in vocational guidance completed by me developed skills for analyzing social trends (e.g. } \\
\text { migration processes, ageing, globalization) and their impact on the labor market }\end{array}$ & 4.23 \\
\hline 11 & $\begin{array}{l}\text { The training in vocational guidance completed by me included topics related to competences and occupations } \\
\text { of the future }\end{array}$ & 4.94 \\
\hline 12 & $\begin{array}{l}\text { The training in vocational guidance completed by me included issues related to cause and effect analysis in } \\
\text { the context of the labor market as a complex system }\end{array}$ & 4.28 \\
\hline 13 & $\begin{array}{l}\text { The training in vocational guidance completed by me provided students with methods/techniques for } \\
\text { analyzing variability and uncertainty in the context of career planning processes }\end{array}$ & 4.19 \\
\hline 14 & $\begin{array}{l}\text { The training in vocational guidance completed by me provided students with the opportunity to learn } \\
\text { methods of activating and involving the group (e.g. in the form of an educational board game, brainstorming, } \\
\text { project method) }\end{array}$ & 5.01 \\
\hline 15 & $\begin{array}{l}\text { The training in vocational guidance completed by me included universal content allowing for individual and } \\
\text { group counseling in every social group and for people at every age }\end{array}$ & 5.11 \\
\hline 16 & $\begin{array}{l}\text { The training in vocational guidance completed by me enabled the choice of one specialization adapted to } \\
\text { the specificities of current or future work practice (e.g. guidance for adults, work with young people, career } \\
\text { planning, etc.) }\end{array}$ & 3.75 \\
\hline 17 & $\begin{array}{l}\text { Program content of the training in vocational guidance completed by me were updated according to scientific } \\
\text { and technological trends }\end{array}$ & 3.96 \\
\hline 18 & The classes in my vocational guidance training, were conducted by practitioners of vocational counseling & 5.03 \\
\hline 19 & $\begin{array}{l}\text { The teaching staff conducting the classes within my training in vocational guidance included specialists in } \\
\text { economics }\end{array}$ & 3.94 \\
\hline 20 & $\begin{array}{l}\text { The teaching staff conducting the classes within my training in vocational guidance included specialists in } \\
\text { sociology }\end{array}$ & 4.46 \\
\hline 21 & $\begin{array}{l}\text { The teaching staff conducting the classes within training in vocational guidance included specialists in } \\
\text { psychology }\end{array}$ & 5.39 \\
\hline 22 & $\begin{array}{l}\text { The teaching staff conducting the classes within my training in vocational guidance efficiently moderated the } \\
\text { group processes }\end{array}$ & 4.73 \\
\hline 23 & $\begin{array}{l}\text { The atmosphere in the classes of the training in vocational guidance completed by me was conducive to open } \\
\text { and free discussion }\end{array}$ & 5.71 \\
\hline 24 & $\begin{array}{l}\text { Training in vocational guidance enabled me to acquire the ability to take a different perspective, understand } \\
\text { and accept different points of view }\end{array}$ & 5.14 \\
\hline
\end{tabular}

The smallest gap $(-0.56)$ in the perception of completed education and ideal education was noted in the case of sociology specialists who provide vocational guidance (statement 21) and in the case of the classroom atmosphere (-0.91), which by definition should encourage open and free discussion (statement 23). The presented results may prove a high degree of satisfaction with the aforementioned components of the completed education and their conformity with expectations. The most important thing in formulating conclusions from the results obtained using the SERVQUAL method is to strive for a state where there are no gaps. Therefore, in the last stage of the analysis, an average gap was calculated for all statements, which was at the level of (-1.95) (Table 5).

Taking into account the seven-point scale of assessments, in the opinion of the authors of this article, the observed gaps indicate the existence of significant differences between the perception of completed vocational counseling courses and the expectations of respondents in this area. Therefore, 
Table 4. The Assessment of Statements Relating to Ideal Vocational Guidance Training

\begin{tabular}{|c|c|c|}
\hline & Statement & Arithmetic mean \\
\hline 1 & The teaching staff in the ideal vocational counseling training uses modern educational tools & 6.37 \\
\hline 2 & The teaching staff in the ideal vocational counseling training uses interactive educational games & 6.11 \\
\hline 3 & The teaching staff in the ideal vocational counseling training uses interactive whiteboards for group work & 5.72 \\
\hline 4 & The teaching staff in the ideal vocational counseling training uses dedicated online games & 5.82 \\
\hline 5 & Ideal training in vocational guidance develops the ability to formulate personal and professional goals & 6.52 \\
\hline 6 & Ideal training in vocational guidance develops the ability to create alternative (optional) career paths & 6.51 \\
\hline 7 & Ideal training in vocational guidance develops students' ability to inspire others to pursue lifelong learning & 6.52 \\
\hline 8 & $\begin{array}{l}\text { Ideal training in vocational guidance develops students' skills in analyzing technological trends (e.g. } \\
\text { automation, robotization, digitalisation) and their impact on the labor market }\end{array}$ & 6.11 \\
\hline 9 & $\begin{array}{l}\text { Ideal training in vocational guidance develops students' skills in analyzing economic trends (e.g. factors } \\
\text { shaping labour demand, wage levels, shortage and surplus occupations) and their impact on the labor market }\end{array}$ & 6.35 \\
\hline 10 & $\begin{array}{l}\text { Ideal training in vocational guidance develops students' skills in analyzing social trends (e.g. migration } \\
\text { processes, ageing, globalization) and their impact on the labor market }\end{array}$ & 6.29 \\
\hline 11 & Ideal training in vocational guidance covers issues related to competences and occupations of the future & 6.57 \\
\hline 12 & $\begin{array}{l}\text { Ideal training in vocational guidance includes issues related to cause and effect analysis in the context of the } \\
\text { labor market as a complex system }\end{array}$ & 6.29 \\
\hline 13 & $\begin{array}{l}\text { Ideal training in vocational guidance provides knowledge of methods/techniques of analysis of variability and } \\
\text { uncertainty in the context of career planning processes }\end{array}$ & 6.33 \\
\hline 14 & $\begin{array}{l}\text { Ideal training in vocational guidance provides students with the knowledge of methods of activating and } \\
\text { involving the group (e.g. in the form of an educational board game, brainstorming, project method) }\end{array}$ & 6.47 \\
\hline 15 & $\begin{array}{l}\text { Ideal training in vocational guidance includes universal content for individual and group guidance in every } \\
\text { social group and for people at every age }\end{array}$ & 6.50 \\
\hline 16 & $\begin{array}{l}\text { Ideal vocational guidance training enables the selection of one specialization adapted to the specificities of } \\
\text { current or future professional practice (e.g. guidance for adults, work with young people, career planning, } \\
\text { etc.) }\end{array}$ & 5.42 \\
\hline 17 & $\begin{array}{l}\text { Program content within ideal vocational guidance training is updated according to scientific and } \\
\text { technological trends }\end{array}$ & 6.24 \\
\hline 18 & During ideal training in vocational guidance, classes are conducted by practitioners of vocational guidance & 6.47 \\
\hline 19 & $\begin{array}{l}\text { The teaching staff conducting the classes within ideal vocational guidance training includes specialists in } \\
\text { economics }\end{array}$ & 5.81 \\
\hline 20 & $\begin{array}{l}\text { The teaching staff conducting the classes within ideal vocational counseling training moderates the group } \\
\text { process efficiently during the classes }\end{array}$ & 6.35 \\
\hline 21 & $\begin{array}{l}\text { The teaching staff conducting the classes within ideal vocational guidance training includes specialists in } \\
\text { sociology }\end{array}$ & 5.94 \\
\hline 22 & $\begin{array}{l}\text { The teaching staff conducting the classes within ideal vocational guidance training includes specialists in } \\
\text { psychology }\end{array}$ & 6.41 \\
\hline 23 & The atmosphere in the classes of the ideal vocational guidance training promotes open and free discussion & 6.62 \\
\hline 24 & $\begin{array}{l}\text { Ideal training in vocational guidance enables you to acquire the ability to take a different perspective, } \\
\text { understand, and accept different points of view }\end{array}$ & 6.58 \\
\hline
\end{tabular}

it can be assumed that the expectations of respondents as to the quality of educational offerings in the field of vocational counseling are not met.

\section{Measuring the Competency Gap}

The competency gap survey was completed by 240 respondents. The majority of respondents have been actively working as vocational advisors for several years. Almost half of the respondents $(45.8 \%$ of the research sample) are between 35 and 44 years old. About a third of respondents are between 45 and 54 years old, while $14 \%$ are over 54 years old. The least numerous group of advisors (12.5\%) were respondents aged 25 to 34 . Thus, the surveyed career counselors are mainly people over 35 years of age. The interviewed advisors completed various forms of education in vocational counseling. Higher education is the most popular form - over $60 \%$ of the surveyed counselors completed post-graduate studies and another $13 \%$ completed this training during bachelor and master full-time studies. Few advisors attended full-time courses (5\% of the research sample) or online courses ( $3 \%$ of the respondents). The remaining $13 \%$ did not complete vocational counseling education in any of the forms indicated.

As regards the assessment of twelve specific, futures studies and foresight-related competences, the respondents were asked to evaluate the competences 


\section{Figure 2. Ranking of the Average Assessment of Statements in Relation to Vocational Counseling Education}

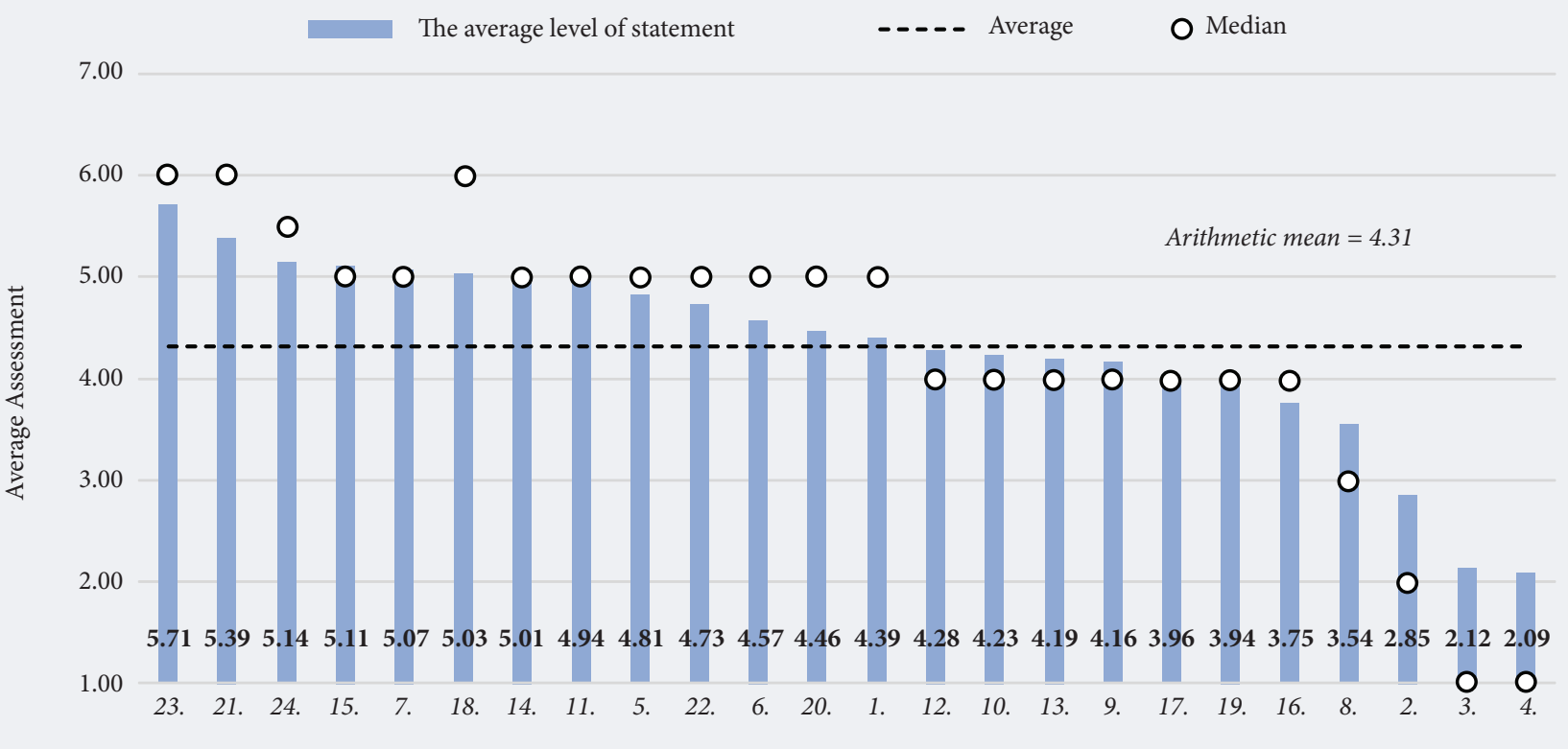

The number of the statement

Source: compiled by the authors.

in two dimensions. The first dimension focused on a self-assessment of the level of competence, the second was related to the assessment of the usefulness of the same competences in the practice of vocational counseling. The aim of the research was to assess the potential competency gaps [Lester, Religa, 2017]. The final list of competences was created based on the areas of "knowledge" and "skills" generated in the previous stage of the study and on expert consultations with vocational counseling practitioners. Generated competences were selected for the final list, including three related explicitly to knowledge and nine to skills. However, some of the statements related to abilities at the same time require specific knowledge, for example, in the field of the labor market. In order to ensure conceptual clarity and

\section{Figure 3. Ranking of the Average Assessments of Statements in Relation to Vocational Counseling Education}

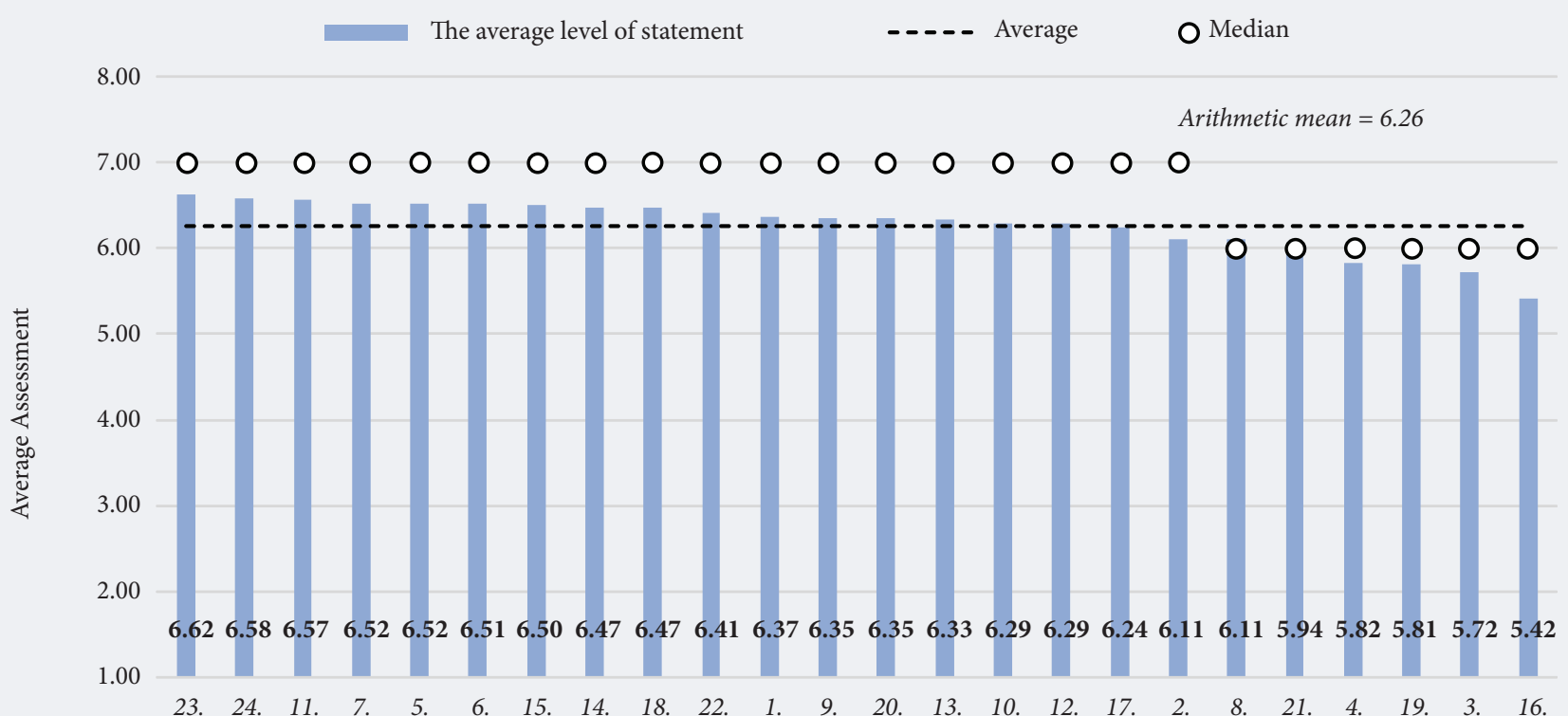

Source: compiled by the authors.

The number of the statement 
Table 5. Ranking of Differences between Average Perceived Values (Completed Course) and Expected Values (Ideal Course)

\begin{tabular}{|c|c|c|c|}
\hline Statements & $\begin{array}{c}\text { Completed } \\
\text { (average) }\end{array}$ & Ideal & Gap \\
\hline $\mathbf{4}$ & 2.09 & 5.82 & -3.73 \\
\hline $\mathbf{3}$ & 2.12 & 5.72 & -3.6 \\
\hline $\mathbf{2}$ & 2.85 & 6.11 & -3.25 \\
\hline $\mathbf{8}$ & 3.54 & 6.11 & -2.57 \\
\hline $\mathbf{1 7}$ & 3.96 & 6.24 & -2.28 \\
\hline $\mathbf{9}$ & 4.16 & 6.35 & -2.2 \\
\hline $\mathbf{1 3}$ & 4.19 & 6.33 & -2.13 \\
\hline $\mathbf{1 0}$ & 4.23 & 6.29 & -2.06 \\
\hline $\mathbf{1 2}$ & 4.28 & 6.29 & -2.01 \\
\hline $\mathbf{1}$ & 4.39 & 6.37 & -1.97 \\
\hline $\mathbf{6}$ & 4.57 & 6.51 & -1.94 \\
\hline $\mathbf{2 0}$ & 4.46 & 6.35 & -1.89 \\
\hline $\mathbf{1 9}$ & 3.94 & 5.81 & -1.87 \\
\hline $\mathbf{5}$ & 4.81 & 6.52 & -1.7 \\
\hline $\mathbf{2 2}$ & 4.73 & 6.41 & -1.68 \\
\hline $\mathbf{1 6}$ & 3.75 & 5.42 & -1.66 \\
\hline $\mathbf{1 1}$ & 4.94 & 6.57 & -1.62 \\
\hline $\mathbf{1 4}$ & 5.01 & 6.47 & -1.47 \\
\hline $\mathbf{7}$ & 5.07 & 6.52 & -1.45 \\
\hline $\mathbf{1 8}$ & 5.03 & 6.47 & -1.44 \\
\hline $\mathbf{2 4}$ & 5.14 & 6.58 & -1.44 \\
\hline $\mathbf{1 5}$ & 5.11 & 6.5 & -1.39 \\
\hline $\mathbf{2 3}$ & 5.71 & 6.62 & -0.91 \\
\hline $\mathbf{2 1}$ & 5.39 & 5.94 & -0.56 \\
\hline AVERAGE & & & -1.95 \\
\hline Source: compiled by the authors. & & \\
\hline & & & \\
\hline & & & \\
\hline
\end{tabular}

obtain the best-quality research results, it was also decided to choose competences that constitute the basic level of competence important from the perspective of futures studies and foresight methodologies in career counseling education and practice while at the same time considering ones that some of vocational counselors may already possess. It was also considered important to translate specialized concepts of foresight and future studies into more general and understandable categories, such as "the ability to interpret signals of impending changes in the external environment (signs of new trends)" instead of "wild cards and weak signals", which could be difficult to interpret by the respondents. The competences are described in Table 6.

For each of the 12 competences indicated in the questionnaire, the arithmetic mean was calculated for the assessments in two dimensions, first in order to examine the individual degree of possession of a competence (self-assessment), and the second, to examine the usefulness of the competence in professional practice.

In terms of first dimension, the self-assessment of the competences, the study results show that 53 respondents lack some of the competences indicated in the questionnaire (rate 1 on the scale, Table 7). Of this group, almost half ( 25 respondents) claim to be incompetent in the knowledge of coaching models (C12). A significant group (121 respondents) indicated a very low level (rate 2) of competence in the following areas: analyzing trends and megatrends on the labor market (C7), using creative techniques during the advisory process (C5), and the ability to interpret signals from the external environment (C8). Therefore, these four competences (namely $\mathrm{C} 12, \mathrm{C} 7, \mathrm{C} 5, \mathrm{C} 8$ ) can be considered weaknesses of vocational counselors in their own opinion. On the other hand, the highest-rated competences were: C9 (205 assessments at levels 4 and 5 in total), C2 (204 assessments at levels 4 and 5), C10 (in total 201 grades at levels 4 and 5), and C1 (200 grades at levels 4 and 5 in total). The results were reflected in the average levels of counselor's assessment by establishing the following competences at the lowest level: C12, C7, C5, and C8. At the same time, the competences $\mathrm{C} 9, \mathrm{C} 2$, and $\mathrm{C} 10$ received the highest levels of self-assessment on average (Table 7).

In terms of the second dimension, from the perspective of career counseling practice, the respondents considered the following competences the most important: C2, C11, C1, C9, and C10. By comparing the average results of self-assessment of respondents' competences and the average of the usefulness of each competence from the vocational advisor's point of view, the differences were obtained, which illustrate competence gaps (Figure 4).

The largest gap can be noted in the same competences that are the advisor's weaknesses, namely: C12 - knowledge of coaching models, C7 - the ability to analyze trends and megatrends, $\mathrm{C} 5$ - the ability to apply creative techniques. The gap has been also defined in the field of the knowledge of coaching tools and techniques (competence C11), in which advisors seem to be rather well-skilled. But it is also considered very useful in the everyday practice of the advisor work - it was given the secondhighest score in terms of the usefulness assessment, so the difference between the studied assessments was significant and thus it has been classified as a competency gap.

Identifying the gap raises many questions, one of which is: Does the education of career counselors in some specific form allow them to become more competent in some aspects? To examine whether any relationship may be observed between the completed form of education in the field of vocational counsel- 
Table 6. Description of Competences under Consideration

\begin{tabular}{|c|l|}
\hline $\begin{array}{c}\text { Code of } \\
\text { competence }\end{array}$ & \multicolumn{1}{|c|}{ Description } \\
\hline C1 & moderating work in a group (e.g. using workshop methods, games, open group discussion) \\
\hline C2 & inspiring others to take action \\
\hline C3 & $\begin{array}{l}\text { system thinking, taking into account the complex nature of the environment, cause-effect relationships, and } \\
\text { unobvious relations between phenomena }\end{array}$ \\
\hline C4 & knowledge and the use of scenario methods (methods of creating alternative career paths) in the advisory process \\
\hline C5 & $\begin{array}{l}\text { the ability to apply creative techniques during the advisory process, (e.g. mind maps, design thinking, visualizations } \\
\text { to create professional plans) }\end{array}$ \\
\hline C6 & the ability to create an individual vision of the professional future \\
\hline C7 & the ability to analyze trends and megatrends affecting the labor market \\
\hline C8 & the ability to interpret signals of impending changes in the external environment (signs of new trends) \\
\hline C9 & the ability to analyze and use data and information from various sources and the ability to infer on this basis \\
\hline C10 & the ability to adapt and understand a different perspective, overcoming the existing patterns of thinking \\
\hline C11 & $\begin{array}{l}\text { knowledge of coaching tools and techniques for effective interpersonal communication (e.g. ability to ask the right } \\
\text { questions, paraphrasing) }\end{array}$ \\
\hline C12 & knowledge of coaching models aimed at working with clients' professional goals, e.g. GROW \\
\hline \multicolumn{2}{|l|}{ Source: compiled by the authors. } \\
\hline
\end{tabular}

ing and the assessment of the competences that are most needed, a correspondence analysis was conducted. In the framework of two competences C12 knowledge of coaching models and C7 - the ability to analyze trends and megatrends, the competency gaps were the largest. So, the relationship between three variables was analyzed: form of education received advisors' self-assessment of competence C12 and advisors' self-assessment of competence C7. Extending the set of variables could make the results difficult to interpret or illegible. The correspondence analysis is a descriptive and exploratory technique of analysis of two-dimensional and multi-dimensional contingency tables used to detect relationships and present the structure of qualitative variables. It should be noted that correspondence analysis is an exploratory technique, so no inference about the statistical significance of its findings can be drawn. Nevertheless, it may provide an interesting insight for further analysis. The main advantage of this method is that it can be applied to data with less stringent properties [Greenacre, 1984, p. 259]. Further, no assumption on the data distribution has to be made. The results of the analysis can be also presented graphically, which allows for drawing conclusions on the similarity between the categories of variables [Gatnar, Walesiak, 2004, p. 284]. A detailed description of the method can be found in [Greenacre, Hastie, 1987; Greenacre, 1993; Błaczkowska et al., 2012; Gatnar, Walesiak, 2004]. The map of perception for variables: a form of education received and advisors' self-assessments of competence C12 and C7 is presented in Figure 5.

\section{Figure 4. Ranking of the Competency Gaps between the Average Usefulness of Relevant Competencies and Average Self-Assessment}

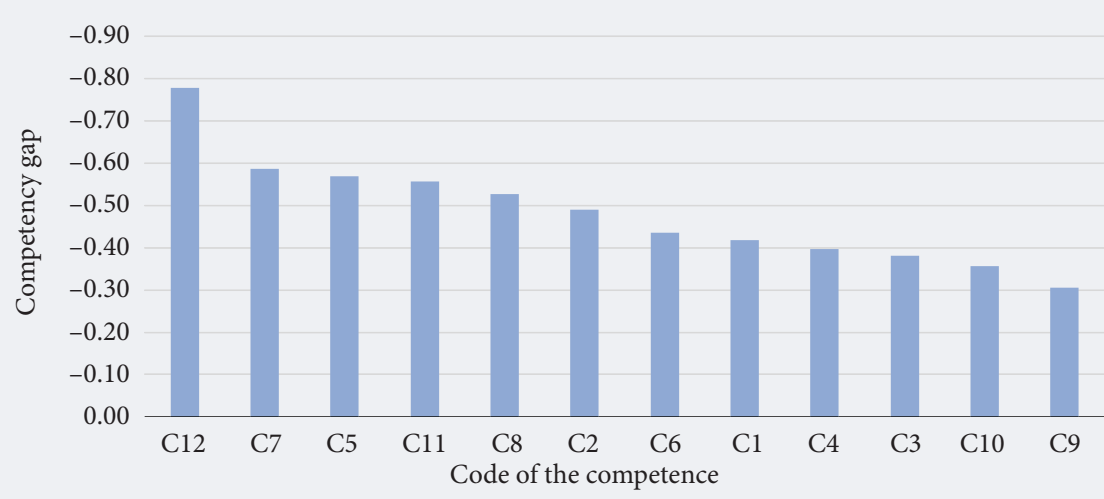

Source: compiled by the authors. 
Table 7. Competency Assessment Results

\begin{tabular}{|c|c|c|c|c|c|c|c|c|}
\hline \multirow[t]{2}{*}{$\begin{array}{l}\text { Code of } \\
\text { competence }\end{array}$} & \multicolumn{5}{|c|}{$\begin{array}{c}\text { Number of self-assessments in the area of each competence } \\
\text { from } 1 \text { - «I do not have competence in this area» to } 5 \text { - «I have } \\
\text { very high competence in this area» }\end{array}$} & \multirow[t]{2}{*}{$\begin{array}{l}\text { Average of self- } \\
\text { assessment }\end{array}$} & \multirow{2}{*}{$\begin{array}{l}\text { Average } \\
\text { of the } \\
\text { usefulness } \\
\text { assessment }\end{array}$} & \multirow[t]{2}{*}{$\underset{\text { gap }}{\text { Competency }}$} \\
\hline & 1 & 2 & 3 & 4 & 5 & & & \\
\hline $\mathrm{C} 1$ & 2 & 5 & 33 & 109 & 91 & 4.18 & 4.59 & -0.42 \\
\hline $\mathrm{C} 2$ & 0 & 1 & 35 & 118 & 86 & 4.21 & 4.70 & -0.49 \\
\hline $\mathrm{C} 3$ & 1 & 8 & 47 & 109 & 75 & 4.04 & 4.42 & -0.38 \\
\hline $\mathrm{C} 4$ & 3 & 10 & 47 & 100 & 80 & 4.02 & 4.41 & -0.40 \\
\hline C5 & 11 & 10 & 61 & 87 & 71 & 3.82 & 4.39 & -0.57 \\
\hline C6 & 3 & 9 & 46 & 97 & 85 & 4.05 & 4.49 & -0.44 \\
\hline C7 & 2 & 20 & 58 & 106 & 54 & 3.79 & 4.38 & -0.59 \\
\hline $\mathrm{C} 8$ & 2 & 16 & 53 & 112 & 57 & 3.86 & 4.38 & -0.53 \\
\hline C9 & 1 & 1 & 33 & 107 & 98 & 4.26 & 4.56 & -0.31 \\
\hline $\mathrm{C} 10$ & 0 & 4 & 35 & 111 & 90 & 4.20 & 4.55 & -0.36 \\
\hline $\mathrm{C} 11$ & 3 & 14 & 44 & 81 & 98 & 4.08 & 4.64 & -0.56 \\
\hline $\mathrm{C} 12$ & 25 & 23 & 59 & 82 & 51 & 3.47 & 4.25 & -0.78 \\
\hline Total & 53 & 121 & 551 & 1219 & 936 & 3.998 & 4.48 & -0.486 \\
\hline
\end{tabular}

The perception map allows for detecting the co-occurrence of the categories of analyzed variables - in this case, the answers of counselors to the question about the self-assessment of the competences $\mathrm{C} 7$ and $\mathrm{C} 12$ and the answers about the education they received. It can be seen that those who completed the regular stationary course in the field of vocational counseling most frequently answered that they have a very good knowledge (rate 5) of coaching tools and effective interpersonal communication (e.g. ability to ask the right questions, paraphrasing) techniques and are also very good at analyzing trends and megatrends affecting the labor market. Advisors who finished post-graduate studies or full-time studies on vocational counseling most often claimed that they represent a good (rate 4) level of competence for C7 and a good (rate 4) or medium (rate 3 ) level of competence for C12. Those advisors, who took an online course in the field of vocational counseling, usually assess their level of analyzed competences as medium (note 3) or poor (2). And, what seems quite obvious, these respondents who assessed competences $\mathrm{C} 7$ and $\mathrm{C} 12$ at the lowest level most frequently chose the answer "not applicable (N/A)" to the question about the form of the received education.

An interesting result of the above analysis is connecting the highest level of the two most needed competences with the answer "regular course". Although this conclusion needs to be confirmed by further research and analysis, it may suggest that for now, regular courses give advisors a better chance of gaining knowledge and skills on coaching tools and techniques in effective interpersonal communication as well as trends and megatrends analysis which affect the labor market. Apparently, studying vocational counselling does not always give the same opportunity. Courses programs are usually more flexible with regard to market demands and are also more focused on practical skills and tools. Meanwhile the process of changing and adapting longer-term study programs is usually more difficult to carry out and takes a long time. However, it seems advisable to devote attention to teaching such methods and techniques during full-time or postgraduate studies.

\section{Results of Qualitative Studies}

The qualitative study covered two research areas. The first concerned the determinants of the quality of the educational offerings and the methodology of teaching in the field of vocational counseling. This area included elements such as 1) factors determining the high quality of educational offerings; 2) program contents; 3) didactic methods; 4) didactic aids; 5) competences and qualifications of didactic staff; 6) form of education organization; 7) period of education. The second area refers to the preferred features and functionalities of educational tools used by vocational counselors' teachers, including: 1) the number of users of educational tools; 2) methods used in other teaching areas that can be adopted in vocational counseling; 3 ) the duration of educational games.

Respondents indicated that factors determining the high quality of educational offerings refer to an attractive curriculum, practical experience of tutors (which is currently insufficient), didactic methods ensuring the acquisition of specific communication 
skills, taking into account the latest trends in the labor market during the education process.

Moreover, respondents, identifying relevant program content, pointed the high importance of classes developing soft skills, providing anassessment of competences and coaching skills enabling support for the client in creating a professional career.

According to the majority of respondents, the advisory skills of tutors in the field of setting alternative paths of professional development are important. They are especially crucial in cooperation with young people, using modern communication technologies.

Experts determined that interactive forms of teaching methods are the best such as workshop methods, including role playing, interviews, the analysis of case studies based on real situations, methods adapted from coaching, methods enabling a process approach to the client, or a wide range of creative methods. These methods should equip future counselors with practical skills that they could then use in their professional work.

Such didactic tools as interactive tools, using new technologies, strategic games, simulation games, and workshop classes teach one how to act in specific professional situations, shape soft competences, or support the career counselor in the process of diagnosing the client and are of significant importance to a counselor's work.
Respondents indicated such competences and qualifications of teaching staff, which are important for the implementation of the educational process in the field of vocational counseling, as practical experience, good relativity, positive attitude towards students and listening skills, as well as the ability to work in a group. Experts also pointed to basic analytical competencies that, enable the identification of trends on the labor market, or digital competencies ensuring the pursuit of technological trends.

Post-graduate studies were considered to be the most popular, although not very attractive, form of vocational counselors' education. The need for continuous further education was stressed, especially within the framework of targeted, thematic courses. The participants of qualitative research had a negative attitude towards education in the field of vocational counseling provided in the form of e-learning due to the lack of direct contact with the teacher.

The research shows that the period of education should be strongly determined by the saturation of the content of education with practical knowledge, the use of didactic methods enabling the acquisition of practical skills, and the participation of counseling practitioners. The more contact with practice during education, the shorter period of education may be.

The focus of second research area of qualitative studies was on the preferred features and functionalities of educational tools used by persons educating vocational counselors. Self-Assessment of Competences C12 and C7

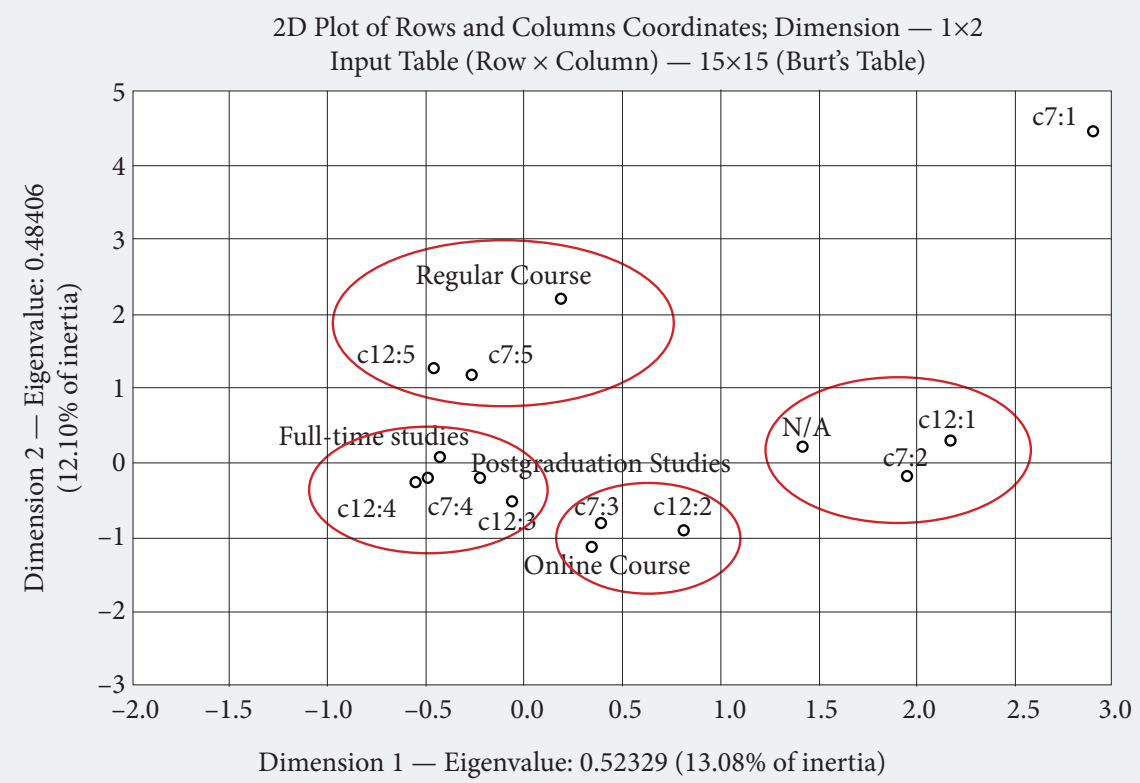

Source: compiled by the authors. 
According to the respondents, career counseling tools cannot replace the contact with a real counselor, but this contact (in the form of an in-depth interview) could support them. The counseling tools should be characterized by the following features: a) involvement, b) flexibility, c) based on real case studies, d) low cost, e) profiling for an appropriate group of clients, f) easy interpretation of the results, $g$ ) intuitive use, and be h) based on group work (4-8 people).

According to the interviewees' knowledge, there are no tools in the Polish advisory system that use the analysis of trends or variants of career development paths. Such a tool would be useful, especially if it is complex, taking into account various aspects of the client's life such as financial, family, and psychological states.

The respondents' statements may suggest a great openness to the introduction and use of new methods and tools both in education and the practice of vocational counseling. Particular attention was paid to creative methods, the use of new technologies (e.g. mobile) and tools for group work involving the group based on selected elements of therapeutic work as well as psychological and pedagogical research.

Two groups of opinions in terms of the optimal duration of the educational game can be distinguished. One group of interviewees emphasized the importance of the process aspect in such games, which would call for a longer cycle of the game. In the second group of respondents, the answers were concentrated on one meeting lasting no more than 3 hours.

An important conclusion from the qualitative study is the opinion of career counselors that it is necessary to reformulate the thinking related to the future of the labor market and to focus on the "competences of the future" and not on specific "professions of the future".

\section{Discussion}

Although uncertainty is omnipresent on the labor market, attempts are being made to create a vision of the future of work [Balliester, Elsheikhi, 2018]. Global labor markets are undergoing major transformations. One may witness a shift in the line between human and machine tasks and algorithms, which should create new opportunities for the training of employees [AfDB et al., 2018]. The major challenges for career counselors should reflect new perspectives and consider the complexities of social change [Pryor, Bright, 2018]. Nevertheless, the issues of the trend analysis and creating alternative paths of career development are neglected in the curricula. The research carried out in Poland demonstrated significant differences between the perception of completed vocational guidance courses and the expectations of career counselors for such courses. An interesting aspect of the research is the fact that, the survey was complemented by a larger number of respondents than expected. A significantly higher number of responses was obtained than was assumed, which indicates a strong need for changes in the environment for career advisors. Taking into account the challenges of Industry 4.0 [Nosalska, Mazurek, 2019], trends analysis, and the scenarios of career path development should be fundamental methods used by career guidance practitioners. On the basis of the analysis carried out, it can also be concluded that the theme of the scientific and technological trends, such as automation, robotization, and digitization, which are a subject of interest of the present study, is treated marginally within the framework of the education completed by the respondents. Also, the methods for the analysis of alternative career paths seem to be neglected in the counseling practice. In the way, both hypotheses of the research have been verified.

The authors of the research also note the limitations of the applied research methods. The SERVQUAL model used in the quantitative part of the research proved to be a very useful framework for gap identification between the perceived and desired state of the phenomena. However, the dimensions of the model need to be adapted to the area in which the research is being carried out. Moreover, the context of the study sometimes implies a deviation from weighing the dimensions due to the significantly asymmetrical division of statements, which was the case in the present study.

In turn, the limitation of qualitative research was looking at the problem of the determinants of the quality of the educational offering and methodology of teaching in the field of vocational counseling as well as the features and functionalities of educational tools used by vocational counselors' teachers from the point of view of one side of the consultancy service - career counselors. Counseling teachers and recipients of counseling services were not examined as the assumptions of the DIALOG project did not include those groups of respondents. However, considering the opinions of various stakeholders is important for a full analysis of which aspects what determine the perspective for future research.

\section{Conclusions}

The current labor market is strongly influenced by technological progress and the so-called fourth industrial revolution. Not only does it change the expectations of employers regarding the qualifications and competences of employees, but also determines the specificity of career counseling process. The research findings presented in this paper indicate that the analysis of scientific and techno- 
logical trends such as automation, robotization, and digitization, is treated marginally in the process of educating career counselors. Simultaneously, there are high expectations toward the consideration of science and technology trends, economic trends, as well as social trends in the content of the education of career counselors. Career counselors expect the teaching staff educating advisors to use dedicated online games or interactive educational games.

With regard to the current and preferred quality of the educational offerings, respondents highlighted a number of key issues. It is crucial for the didactic process of career counseling to implement classes conducted by practitioners, especially from the area of business, entrepreneurship, and selected industries. Moreover, it is important for the students to acquire the necessary communication skills for different groups of clients, including the fluent use of modern communication technologies or soft skills with coaching content. It was also noted that the current educational system for counselors definitely lacks education about the latest social, scientific, and technological trends shaping the labor market.

Another important issue discussed during the qualitative study was the question of the future of the labor market. It was emphasized that the current educational programs lack information about the "competences of the future", that is, there is a lack of information that would allow for the anticipative construction of various career paths in terms of the process approach. At the same time, the high importance of the content (which so far is definitely lacking) ensuring knowledge about the identification of alternative career paths was stressed. According to the respondents, the future of the profession of the career counselor will be influenced mainly by two factors: 1) technological changes, for example, in the form of automation and 2) or sociodemographic changes such as population ageing.
The traditional education of career counseling based on direct contact with the teacher via, for example, post-graduate studies, but with the need to modify them with the implementation of practical classes, was considered the most beneficial. Educational tools used by people educating vocational counselors should be based on group work.

\section{Originality and Value of the Present Study}

Taking into account the challenges faced by modern career counseling, the adaptation of methodologies for studying the future to advisory and educational practice seems to be an original approach. Basic knowledge and skills referring to the exploration and "use" of the future in various fields - so-called futures literacy - is considered the ability to create and process complex visions of the future and give them a new meaning. The approach of the "Horizons of the Future" Project is a unique proposition, based on interdisciplinary knowledge combining career counseling and planning with future studies and foresight methodology. Therefore, one of the important questions the authors of this study are asking throughout the project is the one about the attitude of vocational counselors toward the future, especially in the dimension of professional practice. The authors have taken on the challenge to collectively create a working methodological tool for successful career counseling, which is based on the mysterious and abstract category that is the future, which is both complex and uncertain.

\footnotetext{
This study was carried out within the framework of the "Horizons of the Future" project, which is run under the "Dialogue" Program of the Ministry of Science and Higher Education. The project is implemented by Łukasiewicz Research Network - Institute for Sustainable Technologies in Radom in partnership with the Bialystok University of Technology.
}

\section{References}

AfDB, ADB, EBRD, IDB (2018) The Future of Work: Regional Perspectives, Abidjan (Côte d'Ivoire), Manila (Philippines), London (UK), Washington, D.C.: African Development Bank (AfDB), Asian Development Bank (ADB), European Bank for Reconstruction and Development (EBRD), Inter-American Development Bank (IDB). Available at: https:// publications.iadb.org/en/future-work-regional-perspectives, accessed 10.10.2019.

Ahmed R.R., Vveinhardt J., Štreimikienė D., Ashraf M., Channar Z.A. (2017) Modified SERVQUAL model and effects of customer attitude and technology on customer satisfaction in banking industry: Mediation, moderation and conditional process analysis. Journal of Business Economics and Management, vol. 18, no 5, pp. 974-1004.

Ali S.S., Kaur R., Pande M.J.C., Ahmad F. (2014) Service quality gap approach: A case of Indian customer's satisfaction of private banks. International Journal of Business Excellence, vol. 7, no 4, pp. 429-453.

Balliester T., Elsheikhi A. (2018) The Future of Work: A Literature Review (Research Department Working Paper no 29), Genève (Switzerland): International Labour Office. Available at: https://www.ilo.org/global/research/publications/ working-papers/WCMS_625866/lang--en/index.htm, accessed: 01.10.2019. 
Bednarczyk Z., Domhof L., Nosarzewski K. (2018) Surfing the future of education. What skills, attitudes and knowledge should the educational system aim to develop to address future needs?, Warszawa: Polskie Towarzystwo Studiów nad Przyszłością \& Futures Literacy KnowLabs. Available at: file://C:/Users/oem/Downloads/Surfing_the_future_of_education\%20(1).pdf, accessed 10.09.2019.

Bielecki J., Dziedzic A., Rosak M., Szczuka K., Żochowska E. (2015) Ramowy Program Studiów Podyplomowych z zakresu doradztwa edukacyjno-zawodowego [Framework Program of Postgraduate Studies in the field of educational and vocational counseling], Warszawa: Krajowy Ośrodek Wspierania Edukacji Zawodowej i Ustawicznej (in Polish).

Błaczkowska A., Grześkowiak A., Król A., Stanimir A. (2012) Wykorzystanie analizy korespondencji w badaniu czynników różnicujących wyniki z dwóch części egzaminu gimnazjalnego uzyskanych przez uczniów z różnych obszarów terytorialnych [The use of correspondence analysis in the study of factors differentiating the results of two parts of the junior high school exam obtained by students from different territorial areas]. Przeglad Statystyczny (Statistical Review), vol. 59, no 2, pp. 163-178.

CEDEFOP (2009a) Modernising vocational education and training. Fourth report on vocational education and training research in Europe: Executive summary (Report of the European Centre for the Development of Vocational Training (CEDEFOP)), Luxembourg: Publications Office of the European Union.

CEDEFOP (2009b) Professionalising career guidance. Practitioner competences and qualification routes in Europe (Report of the European Centre for the Development of Vocational Training (CEDEFOP)), Luxembourg: Publications Office of the European Union.

Dauwalder J.P. (2014) From heuristic to life-designing. New tool for coping with complex situations. Available at: https:// www.researchgate.net/publication/310458494, accessed 01.10.2019.

DHET (2016) Competency Framework for Career Development Practicioners in South Africa, Preatoria (SAR): Department of Higher Education and Training (DHET).

Dubois D., Rothwell W. (2004) Competency-based or a traditional approach to training. $T$ and $D$, vol. 58 , no 4 , pp. 46-57.

Ejdys J., Gudanowska A., Halicka K., Kononiuk A., Magruk A., Nazarko J., Nazarko Ł., Szpilko D., Widelska U. (2019) Foresight in Higher Education Institutions: Evidence from Poland. Foresight and STI Governance, vol. 13, no 1, pp. 77-89.

Fernández-Sanz L., Gómez-Pérez J., Castillo-Martínez A. (2017) e-Skills Match: A framework for mapping and integrating the main skills, knowledge and competence standards and models for ICT occupations. Computer Standards \& Interfaces, vol. 51, pp. 30-42.

Flum H., Blustein D.L. (2000) Reinvigorating the study of vocational exploration: A framework for research. Journal of Vocational Behavior, vol. 56, no 3, pp. 380-404.

Gatnar E., Walesiak M. (2004) Metody statystycznej analizy wielowymiarowej w badaniach marketingowych [Methods of statistical multivariate analysis in marketing research], Wroclaw: Wydawnictwo Akademii Ekonomicznej im. Oskara Langego we Wroclawiu (in Polish).

Greenacre M.J. (1984) Theory and Apllications of Correspondence Analysis, London: Academic Press.

Greenacre M.J. (1993) Correspondence Analysis in Practice, London: Academic Press.

Greenacre M.J., Hastie T. (1987) The geometric interpretation of correspondence analysis. Journal of the American Statistical Association, vol. 82, pp. 437-447.

Guan Y., Zhuang M., Cai Z., Ding Y., Wang Y., Huang Z., Lai X. (2017) Modeling dynamics in career construction: Reciprocal relationship between future work self and career exploration. Journal of Vocational Behavior, vol. 101, pp. 21-31.

Hiebert B., Neault R. (2013) Career Counselor Competencies and Standards: Differences and Similarities Across Countries. Available at: file:///C:/Users/oem/Downloads/HNeault-Springer300303_1_En_39_DeltaPDF.pdf, accessed 25.09.2019.

Jiang Z., Newman A., Le H., Presbitero A., Zheng C. (2019) Career exploration: A review and future research agenda. Journal of Vocational Behavior, vol. 110, pp. 338-356.

Knapper Ch. K., Cropley A.J. (2000) Lifelong Learning in Higher Education, London: Kogan Page Limited.

Kononiuk A., Gudanowska A., Magruk A., Sacio-Szymańska A., Fantoni G., Trivelli L., Ollenburg S. (2017a) The quest for the competences of a future-oriented individual: Research methodology and findings. Becoming future-oriented entrepreneurs in universities and companies report, Brussels: European Commission. Available at: http://futureoriented. eu/downloads/, accessed 05.10.2019.

Kononiuk A., Sacio-Szymańska A., Gáspár, J. (2017b) How do companies envisage the future? Functional foresight approaches. Engineering Management in Production and Services, vol. 9, no 4, pp. 21-33.

Kononiuk A.(ed.), Pająk A.(ed.), Gudanowska A., Kononiuk A., Kozłowska J., Magruk A., Pająk A., Rollnik-Sadowska E., Sacio-Szymańska A. (2019) Projektowanie kariery zawodowej - perspektywa badań foresightowych [Career design the perspective of foresight research], Białystok: Oficyna Wydawnicza Politechniki Białostockiej (in Polish). 
Lester S., Religa J. (2017) „Competence” and occupational standards: Observations from six European countries. Education+Training, vol. 59, no 2, pp. 201-214.

Magruk A. (2017) Concept of uncertainty in relation to the foresight research. Engineering Management in Production and Services, vol. 9, no 1, pp. 46-55.

McClune B., Jarman R. (2010) Critical Reading of Science-Based News Reports: Establishing a Knowledge, Skills and Attitudes Framework. International Journal of Science Education, vol. 32, no 6, pp. 727-752.

Mocker D.W., Spear G.E. (1982) Lifelong learning: Formal, nonformal, informal and self-directed (ERIC Information Series Paper no 241), Columbus, OH: National Center for Research in Vocational Education (ERIC). Available at: https://files.eric.ed.gov/fulltext/ED220723.pdf, accessed 20.09.2019.

Nazarko J. (2013) Regionalny Foresight gospodarczy. Metodologia i instrumentarium badawcze [Regional economic foresight. Methodology and research instruments], Warszawa: Związek Pracodawców Warszawy i Mazowsza (in Polish).

NCDA (2009) Career Counselling Competencies, Broken Arrow, OK: National Career Development Association (NCDA). Available at: https://www.ncda.org/aws/NCDA/page_template/show_detail/37798?model_name=news_article, accessed 29.09.2019.

Neureiter M., Traut-Mattausch E. (2017) Two sides of the career resources coin: Career adaptability resources and the impostor phenomenon. Journal of Vocational Behavior, vol. 98, pp. 56-69.

Nosalska K., Mazurek G. (2019) Marketing principles for Industry 4.0 - a conceptual framework. Engineering Management in Production and Services, vol. 11, no 3, pp. 9-20.

OECD (2004) Career Guidance and Public Policy. Bridging the Gap, Paris: OECD. Available at: https://www.oecd.org/ education/innovation-education/34050171.pdf, accessed 28.09.2019.

OECD (2017) Getting Skills Right: The OECD Skills for Jobs Indicators, Paris: OECD. Available at: https://www. oecdskillsforjobsdatabase.org/data/country_notes/Poland\%20country\%20note.pdf, accessed 28.09.2019.

Oyserman D., Bybee D., Terry K. (2006) Possible selves and academic outcomes: How and when possible selves impel action. Journal of Personality and Social Psychology, vol. 91, pp. 188-204.

Parasuraman A., Berry L.L., Zeithaml V.A. (1985) A Conceptual Model of Service Quality and Its Implications for Future Research. Journal of Marketing, vol. 49, no 4, pp. 41-50.

Pryor R.G., Bright J. (2018) Careers as Fractal Patterns: The Chaos Theory of Careers Perspective. Contemporary Theories of Career Development: International Perspectives (eds. N. Arthur, M. McMahon), New York: Routledge, pp. $135-152$.

Rieckmann M. (2012) Future-oriented higher education: Which key competencies should be fostered through university teaching and learning? Futures, vol. 44, no 2, pp. 127-135.

Savickas M.L., Nota L., Rossier J., Dauwalder J., Duarte M.E., Guichard J., Soresi S., Van Esbroeck R., van Vianen A.E.M. (2009) Life designing: A paradigm for career construction in the $21^{\text {st }}$ century. Journal of Vocational Behavior, vol. 75 , pp. 239-250.

Stumpf S., Colarelli S., Hartman K. (1983) Development of the Career Exploration Survey (CES). Journal of Vocational Behavior, vol. 22, pp. 191-226.

Sultana R.G. (2004) Guidance policies in the knowledge society. Trends, challenges and responses across Europe. A CEDEFOP synthesis report, Luxembourg: Office for Official Publications of the European Communities.

Symela K. (2006) Kompetencje i jakość pracy doradcy zawodowego [Competence and quality of work of a vocational counselor], Edukacja dla rynku pracy. Problemy poradnictwa zawodowego [Education for the labor market. Problems of vocational guidance] (eds. S.M. Kwiatkowski, Z. Sirojć), Warszawa: Ochotnicze Hufce Pracy Komenda Główna (in Polish).

Toffler A. (1980) The Third Wave: The Classic Study of Tomorrow, New York: Bantam Books.

Volles N. (2016) Lifelong learning in the EU: Changing conceptualisations, actors, and policies. Studies in Higher Education, vol. 41, no 2, pp. 343-363. 